\title{
ODGOVOR DRŽAVE NA BOLEST COVID-19: NA PRIMJERIMA HRVATSKE I SRBIJE
}

Sažetak: Imajući u vidu trenutnu pandemiju koronavirusa, rad namjerava analizirati odgovor države na bolest koju uzrokuje (COVID-19) s gledišta dviju susjednih država: Republike Hrvatske i Republike Srbije. Posebnu ćemo pozornost posvetiti odgovoru tih država iz perspektive ljudskih prava. Zanimalo nas je koje su modele "borbe" poduzele ove zemlje, posebno koja su ograničenja ljudskih prava odabrana s obzirom na njihov ustavni okvir. Naime, naše polazište je da su ljudska prava često žrtve kriznih situacije i da se lako, a često i nepotrebno i dugo ograničavaju. $S$ tim u vezi, pokušat ćemo odgovoriti na pitanje kakva je kvaliteta i sadržaj ljudskih prava i kako se osigurava zaštita ljudskih prava u ovim iznimnim okolnostima. Ovaj pravni okvir bit će povezan s trenutačnim statistikama u vezi s ovom bolešću.

Ključne riječi: $\quad$ izvanredno stanje, ustav, ljudska prava, derogacija, Hrvatska, Srbija 


\section{UVODNI DIO}

Pandemija koronavirusa (SARS-CoV-2) jedinstven je događaj u novije vrijeme, koji je potpuno poremetio normalni tijek svakodnevnog života u globalnom kontekstu. U novim okolnostima svaka je država, suočena s nepoznatom bolešću, pokušala pronaći uspješan "obrazac" borbe. Takve iznenadne situacije, koje prijete da pogode velike slojeve stanovništva, često dovode do refleksnih radnji nositelja države vlasti u smislu da se odlučuju na ograničavanja ljudskih prava. Polazište je Salus populi, suprema lex, ali to ne smije biti svojevrsni izgovor za privremeno obustavljanje ustavnog poretka i uvođenje "modernog oblika ustavne diktature." U takvim iznimnim situacijama, kako primjećuje Fridrih, država (privremeno) suspendira pravo na temelju prava na samoočuvanje. Izvanredni pravni režim često zahtijeva svjesno žrtvovanje određenih značajnih vrijednosti u obliku zajamčenih prava i sloboda radi jačanja cjelokupnog pravnog poretka. ${ }^{2}$ Međutim, hoće li se pokazati da je riječ o salus populi ili instrumentum manipulationis, ${ }^{3}$ ovisi o ispravnom moderiranju primijenjenih mjera. Ispravno dizajnirane i pravilno implementirane, ove odredbe predstavljaju mehanizam samoobrane za demokraciju i pružaju snagu potrebnu za suočavanje s ozbiljnim prijetnjama.

U ovom radu bavimo se iskustvom dviju susjednih zemalja - Republike Hrvatske i Republike Srbije i promatramo njihov odgovor na pandemiju. Pokušat ćemo odgovoriti na pitanje u kojoj je mjeri ta pandemija utjecala na ustavna jamstva ljudskih prava. U tom smislu počet ćemo s analizom odgovarajućeg ustavnog okvira u navedenim zemljama.

\section{USTAVNI OKVIR IZVANREDNOG STANJA}

Ustavna regulacija izvanrednog stanja i poseban režim važenja ljudskih prava svojstveni su i Ustavu Hrvatske ${ }^{4}$ i Ustavu Srbije. ${ }^{5}$ Postojanje takvih ustavnih normi važno je jer omogućuje vlastima da poduzmu mjere koje zahtijevaju specifičnost određene situacije, ali na način koji državu drži unutar vladavine prava. Davanje carte blanche u uvjetima kada je vlast neizbježno koncentrirana u rukama izvršne vlasti bilo bi rizično zbog mogućih zlouporaba. ${ }^{6}$ Ovo gledište prihvaćeno je u njemačkom Osnovnom zakonu (1949.), slijedeći pogubne odredbe weimarskog Ustava (1919) i Führerprinzip. ${ }^{7}$ Pri dizajniranju ovih odredbi važno je uspostaviti ravnotežu između potrebe za inkluzivnim razmatranjem u odlučivanju, s jedne strane, i potrebom odlučnog i učinkovitog djelovanja, s druge strane. Te bi norme trebale biti mehanizam

1 Fridrih, K., Konstitutcionalna demokratija: Teorija i praksa u Evropi i Americi, CID, Podgorica, $2005 .$, str. 464.

2 Gujančić, D., Vanredno stanje-francusko iskustvo, Politička revija, ,br. 1, 2010., str. 165.-184

3 Avramović, D.; Mlađan, D., Vanredno stanje i vanredna situacija-komparativno terminološki i sadržinski aspekti, Teme, br. 1, 2014., str. 767.-781.

4 Ustav Republike Hrvatske, Narodne novine, broj 56/1990,135/1997, 8/1998, 113/2000,124/2000, 28/2001, 41/2001,55/2001, $76 / 2010,85 / 2010,5 / 2014$.

5 Ustav Republike Srbije, Službeni glasnik RS, broj 98/2006.

6 Ackerman, B., The Emergency Constitution, The Yale Law Journal, Vol. 113, No. 5, 2003-2004, str. 1029.-1091.

7 Pravo potječe od države koju utjelovljuje Führer. Vidjeti: Tucak, I., Pravna misao Hermanna U. Kantorowica $i$ vrijeme nacionalsocijalizma, Zbornik Pravnog fakulteta u Zagrebu, br. 69, 2019., str. 681.-714. 
samoobrane demokracije, tj. način da se osigura demokratska otpornost kada se država suoči s ozbiljnim prijetnjama i izazovima. ${ }^{8}$ Neke zemlje poput Portugala, Španjolske i Grčke, poučene prethodnim iskustvom, detaljno su predvidjele ustavna pravila u izvanrednim situacijama. Ostali ustavi sadrže vrlo malo ili ne sadrže odredbe za hitne nadležnosti i ovlasti. Umjesto toga, oni ustanovljavaju pravila koja omogućavaju brže donošenje odluka u parlamentu kad god je to potrebno. Europski se ustavi razlikuju ne samo s obzirom na postojanje i reguliranje izvanrednih stanja, već i s obzirom na sadržaj: ulozi koju daju parlamentima, zaštiti temeljnih sloboda i jamstvima za opstanak demokratskog političkog poretka. ${ }^{9}$

Ustav Hrvatske priznaje tri vrste izvanrednog stanja: 1. ratno stanje, 2. neposredna ugroženost neovisnosti, jedinstvenosti i opstojnosti Republike, 3. stanje u kome su državna tijela onemogućena u redovitom izvršavanju svojih ustavnih dužnosti. ${ }^{10}$ Ovome se mogu pridodati i velike elementarne nepogode iz čl. 17. Ustava jer njihovo pojavljivanje omogućava ograničavanje sloboda i prava čovjeka i građanina. ${ }^{11}$ Međutim, u Hrvatskoj za vrijeme epidemije koronavirusa ove odredbe Ustava nisu aktivirane, već su se primjenjivale odredbe Zakona o sustavu civilne zaštite. ${ }^{12}$ Možemo primijetiti da je Hrvatska prva poduzela mjere za borbu protiv bolesti COVID-19. Vlada Republike Hrvatske osnovala 20. veljače Stožer civilne zaštite radi koordinacije svih službi u slučaju pojave koronavirusa u Hrvatskoj.

Ustav Srbije sadrži opsežne odredbe o izvanrednom stanju, a pojava koronavirusa bila je prilika da se te odredbe prvi put primijene u praksi. Izvanredno stanje u Srbiji prije ovog slučaja također je uvedeno u ožujku 2003. godine, nakon atentata na premijera Đinđića. Na osnovi tog iskustva kreirana su rješenja u Ustavu Republike Srbije (2006). Izvanredno stanje može se proglasiti kada javna opasnost prijeti opstanku države ili građana. ${ }^{13}$ To je stanje javne opasnosti u kojem je ugrožen opstanak države ili građana, a posljedica je vojnih ili nevojnih izazova, rizika i prijetnji sigurnosti. ${ }^{14}$ Izvanredno stanje uvodi se zbog terorističkih napada i drugih prijetnji javnom redu i teritorijalnom integritetu, ali i zbog epidemioloških bolesti ljudi. Ustavni sud Srbije potvrdio je da bi se pojava zarazne bolesti COVID-19 i opasnost od nekontroliranog širenja mogla smatrati opasnošću koja značajno ugrožava zdravlje opće populacije, što ugroržava normalan tijek života u zemlji, uključujući i funkcioniranje njezinih institucija, javnih službi, a naročito zdravstvenog sustava. ${ }^{15}$

Pravni poredak Srbije poznaje i izvanrednu situaciju koja je zakonski regulirana. ${ }^{16}$ Izvanredna situacija je stanje koje nastaje proglašavanjem nadležnog tijela kada su rizici i prijetnje ili posljedice za stanovništvo, okoliš i materijalna i kulturna dobra takvog obujma i intenzi-

8 Bulmer E., Emergeny Powers, International IDEA, Sweden, 2018., str. 6

9 Khakee, A., Obezbeđivanje demokratije? Komparativna analiza nadležnosti vanrednog stanja Evropskih zemalja, https://www. dcaf.ch/sites/default/files/publications/documents/PP30-Anna-Khakee-Emergency-Powers-Serbian-final.pdf. Pristupljeno 12. travnja 2020.

Članak 101 Ustava Hrvatske.

Omejec, J., Ograničavanje sloboda i prava čovjeka i građanina u izvanrednim stanjima, Društveno istraživanje Zagreb, god. 5, br. 2, 1996., str. 345.-376.

Zakon o sustavu civilne zaštite, Narodne novine, broj 82/2015, 118/2018, 31/2020.

Članak 200. st. 1.

Članak. 4. st. 1. t. 6. Zakona o odbrani (Službeni glasnik RS, broj 116/2007).

Rješenje Ustavnog suda Srbije IUo-42/2020.

Zakon o smanjenju rizika od katastrofa i upravljanju vanrednim situacijama (Službeni glasnik RS, 87/2018). 
teta da se njihov nastanak ili posljedice ne mogu spriječiti ili ukloniti redovitim djelovanjem nadležnih tijela i službi, zbog čega je za njihovo ublažavanje i otklanjanje potrebno upotrijebiti posebne mjere, snage i sredstva s pojačanim režimom rada. ${ }^{17}$ Tako je pravni sustav Srbije ostavio mogućnosti primjene dva mehanizma "borbe" s koronavirusom. Međutim, Srbija se, za razliku od susjeda, nije opredijelila za blaži oblik narušavanja ustavnog sustava, već je uvela izvanredno stanje.

Odluku o proglašenju izvanrednog stanja u Srbiji ${ }^{18}$ donijeli su predsjednik Republike, predsjednik Narodne skupštine i predsjednik Vlade, iako Ustav određuje parlament kao primarnog donositelja odluke. Samo ako parlament nije u mogućnosti sastati se, odluku donosi sekundarni kolektivni donositelj odluka. ${ }^{19}$ Razlozi zbog kojih se Narodna skupština Srbije nije mogla sastati nisu nigdje formalno navedeni. Iznenađuje stajalište Ustavnog suda da Odluka o uvođenju izvanrednog stanja ne treba biti obrazložena, iako prepoznaje da je ova odluka specifične naravi kojom se država prevodi iz redovnog u izvanredno stanje. ${ }^{20} \mathrm{U}$ okolnostima kada su parlamenti svih ostalih zemalja održavali sjednice, uključujući i Hrvatsku, Narodna skupština Srbije bila je lišena te mogućnosti. No, još je opasnije što je nemogućnost održavanje sjednica parlamenta (neslužbeno) podvedena pod Naredbu ministra zdravlja o zabrani okupljanja više od 50 ljudi na javnim mjestima u zatvorenim prostorima. ${ }^{21} \mathrm{Ti}$ su razlozi, čak i ako su epidemiološkog karaktera, u najmanju ruku ustavnopravno neprihvatljivi. Skupština se prvi put sastala tek 28. travnja, gotovo 45 dana od uvođenja izvanrednog stanja. Parlamentarna većina ostala je dosljedna svom pokornom odnosu prema izvršnoj vlasti ${ }^{22}$ i potvrdila sve odluke i uredbe donesene u stanju državne nužde. Ustavni sud je i za to našao opravdanje: pitanje (ne)mogućnosti zasjedanja Narodne skupština faktičko je a ne pravno pitanje, imajući u vidu da Ustavi drugi pravni akti nisu utvrdili koje su to situacije kad Narodna skupština nije u mogućnosti sastati se, posebno imajući u vidu činjenicu da Ustavni sud ne može procijeniti organizacijske mogućnosti Narodne skupštine da se sastane bez odgađanja u uvjetima opasnosti za život i zdravlje ljudi. ${ }^{23}$

Promatrat ćemo ocjenu opravdanosti uvođenja izvanrednog stanja iz kuta međunarodnopravno prihvatljivih razloga. Europska konvencija za zaštitu ljudskih prava i osnovnih sloboda prepoznaje kao izvanredne okolnosti u kojima je moguć poseban pravni režim vrijeme rata ili druge javne opasnosti koje prijete opstanku nacije. ${ }^{24}$ Europski sud za ljudska prava određuje sljedeće kriterije koji moraju biti ispunjeni da bi postojala javna opasnost: 1. opasnost mora biti stvarna ili neposredna, 2. njezini efekti moraju se odnositi na cijeli narod, 3. kontinuitet organiziranog života zajednice mora biti pod prijetnjom, 4. kriza ili opasnost

\footnotetext{
17 Članak 2. st. 1.t. 7. Zakona.

18 Službeni glasnik RS, broj 29 od 15. ožujka 2020.

19 Jovičić, J., Položaj parlamenta za vreme vanrednog i ratnog stanja u ustavnom sistemu Republike Srbije, Nauka, bezbednost, policija, god. 20, br. 1, 2015., str. 163.-172.

20 Rješenje Ustavnog suda IUo 42/2020 od 22. svibnja 2020.

21 Izjava predsjednice Skupštine objavljena na službenoj stranici SNS-a, 23. ožujka 2020. https://www. sns.org.rs/lat/novosti/ vesti/gojkovic-rizici-i-pretnje-po-bezbednost-gradana-zahtevaju-proglasenje-vanrednog-stanja. Pristupljeno 2. travnja 2020.

22 Pejić, I., The Constitutional rationalization of the separation of powers: the case of Serbia, Zbornik radova Pravnog fakulteta u Nišu, br. 84, 2019., str. 54.

23 Rješenje IUo-42/2020. 
mora biti izuzetna, u smislu da normalne mjere ili ograničenja koja Konvencija dopušta radi održavanja javne sigurnosti, zdravlja ili reda, očigledno nedovoljne. ${ }^{25}$ Pandemija koronavirusa mogla bi se podvesti pod navedene kriterije.

Kada je riječ o odgovoru države na ovakve iznimne okolnosti, Europski sud podsjeća da je na svakoj državi ugovornici, unutar njezine odgovornosti za opstanak nacije, da odredi je li opstanak ugrožen javnom opasnošću i, ako jest, koliko daleko je nužno otići da se ta opasnost prevlada. ${ }^{26}$ Budući da su nacionalna tijela u izravnom i neposrednom kontaktu s uzrokom ove situacije, u boljem su položaju od međunarodnog suca za donošenje odluke o postojanju izvanrednog stanja te o prirodi i opsegu derogiranja potrebnog za njegovo uklanjanje. U skladu s tim, nacionalnim tijelima trebalo bi dati široku slobodu procjene u vezi s ovim pitanjima. Međutim, Europski sud naglašava da države ne uživaju neograničeno diskrecijsko pravo; domaću slobodu ocjenjivanja prati europski nadzor. ${ }^{27}$ Države moraju imati na umu, čak i u izvanrednom stanju, da bi cilj svih poduzetih mjera trebao biti zaštita demokratskog poretka od prijetnji i da bi trebalo uložiti maksimalne napore za zaštitu vrijednosti demokratskog društva. Svrha proglašenja izvanrednog stanja treba biti legitimna, a ona će to biti kada cilj proglašenja nije usmjeren na uvođenje diktature ili kršenje ljudskih prava, već na uklanjanje ozbiljnih opasnosti i brzo vraćanje zemlje na normalno funkcioniranje. ${ }^{28}$

Ustav Srbije prihvaća terminologiju iz Europske konvencije i govori o javnoj opasnosti, kao razlogu za uvođenje izvanrednog stanja. Međutim, Odluka o uvođenju izvanrednog stanja ne konkretizira javnu opasnost, ${ }^{29}$ niti ta odluka sadrži obrazloženje, tako da s strogo formalnog aspekta ne možemo procijeniti razloge njezina donošenja. Kako je uvođenju izvanrednog stanja prethodila odluka Vlade o proglašenju bolesti COVID-19 izazvane virusom SARS-CoV-2 zaraznom bolešću od 11. ožujka to možemo povezati, uz napomenu da je epidemija ove bolesti proglašena za vrijeme izvanrednog stanja. ${ }^{30}$ Tako da smo imali situaciju da je tijekom izvanrednog stanja proglašena epidemija zarazne bolesti, iako je bio logičan obrnuti poredak stvari: da se izvanredno stanje uvodi zbog epidemije zarazne bolesti.

Srbija je obavijestila Komitet ministara Vijeća Europe o uvođenju izvanrednog stanja. Ministarstvo pravde izvijestilo je o usvojenim preporukama za rad sudova i javnih odvjetništava tijekom izvanrednog $\operatorname{stanja}^{31}$ i drugim aktima donesenima u tim okolnostima.

Ministarstvo pravosuđa Republike Hrvatske također je poslalo obavijest Komitetu ministara u vezi s preporukama upućenim pravosudnim tijelima za vrijeme epidemije koronavirusa. ${ }^{32}$

25 Dutertre, G., Izvodi iz sudske prarkse Evropskog suda za ljudska prava, IMTEC, Sarajevo, 2002., str. 324.

26 Slučaj Aksoy protiv Turske, presuda od 18. prosinca 1996. Izveštaji 1996-VI, stavak 68.-70.

27 Slučaj Branningan i McBride protiv UK, 26. svibnja 1993., stavak 43., serija A br. 258.-B.

28 Mitrović, Lj.; Grbić Pavlović, N.; Pavlović, G., Derogiranje ljudskih prava u vanrednom stanju - slučaj Bosne i Hercegovine, Pravni vjesnik, br. 3-4, 2016., str. 201.-209.

29 Odluka o proglašenju izvanrednog stanja sadrži samo dva stavka. Prvi proglašava izvanredno stanje na području Republike Srbije. Drugi propisuje da odluka stupa na snagu s danom objavljivanja u Službenom glasniku.

30 Naredba o proglašenju epidemije zarazne bolesti COVID-19, Službeni glasnik RS, broj 37 od 19. ožujka 2020.

31 https://www.mpravde.gov.rs/files/PREPORUKE\%20ZA\%20RAD\%20SUDOVA\%20I\%20JAVNIH\%20TU\%C5\%BDILA\%C5\%AOTAVA\%20ZA\%20VREME\%20VANREDNOG\%20STANJA.pdf. Pristupljeno 14. svibnja 2020.

32 https://pravosudje.gov.hr/vijesti/preporuke-za-prevenciju-prenosenja-i-suzbijanje-epidemije-novim-koronaviruso m-sars-cov2-bolesti-covid-19/21707. Pristupljeno 15. svibnja 2020. 
Odgovor Srbije na bolest COVID-19 treba promatrati u kontekstu specifične političke situacije. Dok je koronavirus “osvajao" zemlju po zemlju, Srbija se pripremala za izbore i uveliko se "licitiralo" s mogućim datumom njihova održavanja, iako je jedan oporbeni blok najavio bojkot zbog nedostatka uvjeta za fer i poštene izbore. Treba spomenuti sastanak predsjednika Republike s predstavnicima zdravstvenih i drugih institucija koje sudjeluju u borbi protiv koronavirusa, održanog 26. veljače. ${ }^{33}$ Nakon sastanka održana je konferencija za novinare, a najupečatljivije poruke upućene građanima bile su da je koronavirus "najsmješniji virus u povijesti čovječanstva” i da "žene slobodno putuju u šoping u Italiju, jer one ne obolijevaju”. Nakon toga, predsjednik Republike donio je 4. ožujka Odluku o raspisivanju izbora za narodne poslanike. Vladajuća partija je već sutradan prikupila više do 40.000 potpisa i predala izbornu listu za sudjelovanje na izborima. Prvi potvrđeni slučaj koronavirusa dogodio se sljedećeg dana, 6. ožujka. Kako je broj zaraženih iz dana u dan rastao, Srbija je samo deset dana poslije posegnula za drugom krajnošću i uvela izvanredno stanje. Stupanjem na snagu Uredbe o merama za vreme izvanrednog stanja prekinute su sve izborne aktivnosti u provođenju izbora. Nakon ukidanja izvanrednog stanja (6. svibnja) nadležna izborna povjerenstva donijela su odluku o nastavku i provedbi izbornih aktivnosti, a izbori su zakazani za 21. lipnja. Epidemija je i dalje na snazi, a specifična predizborna atmosfera u mnogome je diktirala odgovor države, a odražavala se ne samo na ostvarivanju prava glasa, već i na niz Ustavom zajamčenih prava. Istodobno, vrijedno je spomenuti da je u Hrvatskoj Sabor donio Odluku o raspuštanju 18. svibnja, ${ }^{34}$ a da su izbori za zastupnike održani 5. srpnja.

\subsection{DEROGACIJA LJUDSKIH PRAVA}

Privremeni opoziv, tj. odstupanje od proklamiranih ljudskih prava, često se događa u izuzetnim okolnostima u kojima se država nađe. Odstupanja od ljudskih prava osobito su problematična jer iskustvo pokazuje da se najozbiljnija kršenja ljudskih prava najčešće događaju u izvanrednim stanjima. Stoga je važno da režim važenja ljudskih prava u stanjima nužde bude pravno reguliran kako bi se suzio prostor za diskrecijske ovlasti državnih tijela.

Pakt o građanskim i političkim pravima (ICCPR) ${ }^{35}$ predviđa da države članice, u vrijeme javne opasnosti koja prijeti životu nacije, mogu poduzeti mjere za odstupanje od svojih obveza prema ovom Paktu. Mjera derogacije od obveza određena je težinom situacije i ona ne smije biti u sukobu s drugim obvezama države prema međunarodnom pravu, niti uključivati diskriminaciju na temelju rase, spola, jezika, vjere ili društvenog podrijetla. ICCPR ne dopušta odstupanje od sljedećih prava: prava na život, zabrane ropstva, zabrane zatvora zbog neispunjenja ugovorne obveze, zabrane retroaktivnost u kaznenom pravu, pravo na pravnu osobnost i slobode mišljenja, savjesti i vjeroispovijesti.

Europska konvencija predviđa da svaka visoka strana ugovornica može, u doba rata ili druge javne opasnosti koja prijeti opstanku nacije, poduzeti mjere koje odstupaju od njezinih

33 https://vucic.rs/Vesti/Najnovije/a37251-U-Srbiji-nema-zarazenih-korona-virusom-vucic.rs.html. Pristupljeno $12 . \quad$ travnja 2020.

34 https://www.sabor.hr. Pristupljeno 18. svibnja 2020. 
obveza prema Konvenciji. Također treba reći da čl. 15. prepoznaje određenu hijerarhiju prava i eksplicite uspostavlja popis prava u odnosu na koja nije dopušteno odstupanje. To su pravo na život, zabrana mučenja, zabrana ropstva i prisilni rad i kažnjavanje samo na temelju zakona. Država može odstupiti od svojih obveza samo u mjeri u kojoj to zahtijeva hitnost situacije. Kada se derogacijom narušavaju prava iz Konvencije, poput prava na slobodu, Europski sud mora biti uvjeren da je riječ o iskrenom odgovoru na stanje opasnosti, u potpunosti opravdano naročitim okolnostima dane opasnosti i da je pružena odgovarajuća zaštita od zlouporabe. Prema mišljenju Suda, pristup prema čl. 15. mora biti usmjeren na opću situaciju u dotičnoj zemlji; kada se utvrdi da su mjere nerazmjerne danoj prijetnji i imaju diskriminirajući učinak, nema potrebe ići dalje i ispitivati njihovu primjenu u konkretnom slučaju svakog podnositelja predstavke. ${ }^{36}$

Pariški minimalni standardi o važenju ljudskih prava u izvanrednom stanju određuju da tijekom izvanrednog stanja osnovne funkcije zakonodavne vlasti moraju ostati netaknute unatoč relativnoj ekspanziji autoriteta izvršne vlasti. Kada je riječ o ljudskim pravima, prepoznaje se mogućnost njihova ograničenja u uvjetima javne opasnosti, ali s postavljanjem granica. Restriktivne mjere moraju biti strogo proporcionalne situaciji i ne smiju voditi diskriminaciji na temelju rase, spola, jezika, vjere, nacionalnosti ili socijalnog podrijetla. Popis prava koja se ne mogu ograničiti uključuje: pravo na pravnu osobnost, zabranu ropstva, zabranu diskriminacije, pravo na život, pravo na slobodu, zabranu mučenja, pravo na pošteno suđenje, slobodu misli, savjesti i vjere, zabranu zatvaranja zbog nemogućnosti ispunjenja ugovorne obaveze, manjinska prava, pravo na brak i zasnivanje obitelji, pravo na ime, prava djeteta, pravo na državljanstvo, pravo na političko sudjelovanje i pravo na pravni lijek. ${ }^{37}$

Kada govorimo o zaštiti ljudskih prava tijekom izvanrednog stanja, u europskim ustavima možemo vidjeti tri kategorije. Neki ustavi (Belgije, Danske, Italije, Slovačke) ne spominju ovo pitanje ili ga prepuštaju zakonskoj regulaciji. Drugi ustavi (Austrije, Grčke, Litve, Malte, Nizozemske) navode prava koja mogu biti ograničena za vrijeme izvanrednog stanja. Treća skupina ustava (Bugarske, Poljske, Mađarske, Slovenije) navodi prava od kojih se ne može odstupiti. ${ }^{38}$ Ustav Hrvatske i Ustav Srbije pripadaju ovoj skupini ustava.

Ustav Hrvatske uspostavlja poseban režim važenja ljudskih prava u doba ratnog stanja, neposrednoj prijetnji neovisnosti i jedinstvu države te velikih prirodnih nepogoda (članak 17.). U takvim uvjetima prava zajamčena Ustavom mogu biti ograničena. Sabor o tome odlučuje dvotrećinskom većinom svih zastupnika, a ako se ne može sastati, odluku donosi predsjednik Republike, na prijedlog Vlade i uz supotpis predsjednika Vlade. ${ }^{39}$ Opseg ograničenja mora biti primjeren naravi pogibelji, a za posljedice ne može imati nejednakost osoba s obzirom na rasu, boju kože, spol, jezik, vjeru, nacionalno ili socijalno podrijetlo. Istodobno, u članku 16. Ustav utvrđuje da se slobode i prava mogu ograničiti samo zakonom da bi se zaštitila sloboda i prava drugih ljudi te pravni poredak, javni moral i zdravlje. U tom smislu, temeljna je ustavna dilema je li osnova za djelovanje u pandemijskim okolnostima zbog pojave bolesti COVID-19 članak

36 Slučaj A. i drugi v. UK, presuda Velikog vijeća od 19. veljače 2009., st. 185.

37 Lillich, R., The Paris Minimum Standards of Human Rights Norms in a State of Emegency, The American Journal of International Law, No. 4, 1985., 1072.-1081. 
16. ili članak 17. Ustava RH. Ovu dilemu razriješio je Ustavni sud utvrdivši da je odluka o tome u isključivoj domeni Hrvatskoga sabora. Ustavni sud nije ovlašten nalagati Hrvatskom saboru koju će od dvije ustavne mogućnosti ograničenja ljudskih prava i osnovnih sloboda odabrati. ${ }^{40}$ No, u oba režima mora se voditi računa o principu proporcionalnosti. ${ }^{41}$ Ustav Hrvatske prepoznaje popis apsolutno zaštićenih prava. To su: pravo na život, zabrana mučenja, surovog ili ponižavajućeg postupanja ili kažnjavanja, pravna određenost kažnjivih djela i kazni, sloboda misli, savjesti i vjeroispovijesti. ${ }^{42}$

Režim važenja ljudskih prava u izvanrednom stanju utvrđen Ustavom Srbije vrlo je sličan rješenju u Ustavu Hrvatske. Nakon proglašenja izvanrednog stanja dopuštena su odstupanja od ljudskih i manjinskih prava zajamčenih Ustavom. Derogaciju prava treba primijeniti samo ako je to nužno i samo u mjeri u kojoj je to potrebno. Mjere odstupanja ne smiju dovesti do razlikovanja prema osnovi rase, spola, jezika, vjere, nacionalnosti ili društvenog podrijetla. Ustav Srbije prepoznaje apsolutno zaštićena prava, u vezi s kojima nisu dopuštena odstupanja. Popis ovih prava je širok i uključuje: dostojanstvo i slobodan razvoj ličnosti, pravo na život, nepovredivost tjelesnog i psihičkog integriteta, zabranu ropstva, položaja sličnog ropstvu i prisilni rad, pravo na pošteno suđenje, pravnu sigurnost u kaznenom pravu, pravo na pravnu osobnost, pravo na državljanstvo, slobodu misli, savjesti i vjeroispovijesti, prigovor savjesti, zabranu izazivanja rasne, nacionalne i vjerske mržnje, pravo na zaključenje braka i ravnopravnost supružnika, slobodu odlučivanja o rađanju djece, prava djeteta i zabranu nasilne asimilacije. Moglo bi se reći da je izričita zabrana promjene Ustava tijekom izvanrednog stanja dodatno jamstvo. ${ }^{43}$ Možemo primijetiti da je popis zaštićenih prava vrlo opsežan i da je ovaj popis najbliži onome koji je uspostavljen Pariškim minimalnim standardima. Ovaj koncept važenja ljudskih prava u izvanrednom stanju predstavlja značajan iskorak u odnosu na prethodno važeći Ustav Srbije (1990) i u skladu je s međunarodnim standardima.

Jedno od osnovnih načela koje karakterizira režim važenja ljudskih prava u izvanrednim uvjetima, koji prepoznaju kako međunarodni dokumenti, tako i ustavi promatranih država, jest načelo razmjernosti. Glavna svrha ovog načela predstavlja pronalaženje pravične ravnoteže između javnog i privatnog interesa; nametnuto ograničenje treba biti nužno i razmjerno cilju koji se time nastojao ostvariti. ${ }^{44}$ Alexy tvrdi da je balansiranje sveprisutno u pravu i da je u slučaju ustavnih prava balansiranje neizbježno. ${ }^{45}$ Načelo proporcionalnosti tako je dobro utvrđeno u ustavnom pravu da tvrdnja da je ustavno pravo zakoračilo u vrijeme balansiranja uopće nije pretjerana. Načelo proporcionalnosti pojavljuje se kao "univerzalni kriterij ustavnosti” ${ }^{46}$ Državne mjere moraju biti prikladne za postizanje određenog cilja, odnosno da nema drugog instrumenta kojim tijelo raspolaže, a koji je manje restriktivan. Prema riječima Saveznog ustavnog suda Njemačke to bi značilo da "intervencija mora biti primjerena i nužna za

\footnotetext{
40 Rješenje Ustavnog suda broj U-I-1372/2020 i dr. (Zakon o sustavu civilne zaštite i Zakon o izmjenama i dopunama Zakona o zaštiti pučanstva od zaraznih bolesti).

41 Članak.16.

42 Članak 17. st. 3. Ustava Hrvatske.

43 Članak 204. Ustava Srbije.

44 Šarin, D., Konvencija za zaštitu ljudskih prava i temeljnih sloboda kroz odnos Europskog suda za ljudska prava i Ustavnog suda Republike Hrvatske na primjeru zaštite ljudskog prava na pristup sudu, Pravni vjesnik, br. 3-4, 2014., str. 77.-100.

45 Alexy, R., On balancing and subsmption. A structural Comaprison, Ratio Juris, Vol. 16, Issues 4, 2003., str. 433.-449. 
postizanje cilja. Ne može se nametnuti pretjerani teret pojedincu o kojem je riječ i mora biti razuman s obzirom na utjecaj koji ima na pojedinca." ${ }^{47}$

\subsection{OGRANIČENJE LJUDSKIH PRAVA I COVID-19}

Protuepidemijske mjere poduzete za sprječavanja širenja bolesti COVID-19 najprije su utjecale na slobodu kretanja i slobodu okupljanja. Bolest COVID-19 je učinila posebno osjetljivim i pravo na privatnost u globalnom kontekstu. Digitalne tehnologije u mnogim državama imale su vrijednu ulogu u borbi protiv bolesti COVID-19. Razvijene su mobilne aplikacije koje se instaliraju na pametne telefone, s različitim funkcijama s ciljem podržavanja borbe protiv virusa. Vlade, u nastojanju da epidemiju drže pod kontrolom, počele su pratiti oboljele preko mobitela. Međutim, kako bi se spriječile moguće zloupotrebe i nedopušteno zadiranje u privatnu sferu, Europski parlament je naglasio da primjena digitalnih mjera u borbi protiv bolesti COVID-19 mora biti u suglasnosti sa zaštitom podataka o osobi i usvojen je odgovarajući vodič upućen državama članicama. ${ }^{48}$ U Hrvatskoj se pokušalo s hitnom izmjenom Zakona o elektroničkim komunikacijama kako bi se omogućilo praćenje mobitela građana koji krše pravila samoizolacije. Prijedlog dopune ovog Zakona odjeknuo je u javnosti i izazvao brojne kritike oporbe i nevladinih organizacija. Odustalo se od donošenja po hitnom postupku i zakonske izmjene su poslane na drugo čitanje.

U Srbiji je formiran Informacioni sistem Covid 19, kao centralizirani softver za unos, analizu i čuvanje podataka o svim osobama koje se prate radi suzbijanja pandemije u Srbiji. Međutim, korisničko ime i lozinka za pristup ovom sistemu bili su javno dostupni na mrežnoj stranici jedne zdravstvene ustanove u trajanju od osam dana. Reakcija je uslijedila odmah nakon prijave i navedeni podaci više nisu javno dostupni. ${ }^{49}$

Ustav Srbije i Ustav Hrvatske sadrže slične formulacije o slobodi kretanja. Ova sloboda zajamčena je svima i uključuje slobodu napuštanja teritorija države, ali i povratka u nju. Te slobode nisu apsolutne i ustavom je dopušteno njihovo ograničavanje zakonom. Ograničenje slobode kretanja dopušteno je, među ostalim, radi sprječavanja širenja zaraznih bolesti (Ustav Srbije), odnosno radi zaštite zdravlja (Ustav Hrvatske). U praksi je to imalo drugačije obrise.

Nakon proglašenja epidemije, Nacionalni stožer civilne zaštite donio je odluku o privremenoj zabrani prelaska graničnih prijelaza Republike Hrvatske; ${ }^{50}$ hrvatski državljani mogu se vratiti, tj. otići u zemlju u kojoj rade, uz primjenu uputa i mjera Hrvatskog zavoda za javno zdravstvo. S obzirom na ubrzano širenje i pojačan rizik prijenosa bolesti uvedena je protuepidemijska mjera strogog ograničavanja zadržavanja na ulicama i drugim javnim mjestima. Ova Odluka odnosi se na ulice, trgove, rive, parkove i sve ostale javne površine na kojima se može

\footnotetext{
47 Emiliou, N., The Principle of Proportionality in European Law, A Comparative Study, Kluwer Law international, 1996.

48 Guidance on Apps supporitng the fight against COVID 19 pandemic in relation to data protection.

49 https://www.sharefoundation.info/sr/pandemija-jedne-lozinke/. Pristupljeno 25. travnja 2020.

50 Odluka o privremenoj zabrani prelaska preko graničnih prijelaza Republike Hrvatske, URbroj 511-01-300-20-2 od 19. ožujka 2020.
} 
kretati i zadržavati veći broj osoba. ${ }^{51}$ Zbog istog razloga donesena je odluka da se dječja igrališta i otvorena sportska igrališta stave izvan uporabe. ${ }^{52}$ Kako je u nekim područjima značajno povećani rizik od prijenosa bolesti COVID-19, kako bi se smanjila mogućnost daljnjeg širenja bolesti, zabranjuje se napuštanje mjesta prebivališta, odnosno stalnog boravišta. ${ }^{53}$ Sve ove odluke imaju opći karakter, primjenjuju se na sve i njihovo trajanje je točno određeno. ${ }^{54}$

Ograničavanje slobode kretanja jedna je od prvih mjera poduzetih i u Srbiji. Međutim, ovo pravo je vrlo selektivno ograničavano i nije postojao jedinstven režim važenja. U kojoj mjeri je pokazana "inventivnost" nositelja ovih mjera najbolje pokazuje činjenica da se Uredba o merama za vreme vanrednog stanja ${ }^{55}$ mijenjala često i više puta tijekom tjedna, s apsurdnim ograničenjima u smislu postojanja posebnih termina za izlazak. ${ }^{56}$ U Srbiji je tako prvi put nakon Drugog svjetskog rata uveden tzv. "policijski sat" u vidu administrativne mjere, koja ograničava kretanje stanovništva u određenom razdoblju. Pretpostavljamo da ova mjera može imati svrhu u uvjetima kada je izvanredno stanje uvedeno zbog ugrožavanja javne sigurnosti, što ovdje nije slučaj. Osim toga, režim slobode odlikovala je potpuna neizvjesnost. Nije neuobičajeno da okolnosti izvanrednog stanja diktiraju česte promjene propisa, zbog prilagodbe specifičnim okolnostima. Međutim, nije bilo poznato koliko će ta mjera trajati, koliko će se dugo primjenjivati; bilo je nužno konzultirati najnoviji broj službenog glasila da biste vidjeli možete li izaći van i koliko dugo možete ostati. Kada je riječ o najstarijim građanima, izostalo je bilo kakvo detaljnije obrazloženje većeg rizika kojem su eventualno izloženi i zbog čega se lišavaju elementarne slobode kretanja.

Na ostvarivanje slobode kretanja utjecala je i Odluka o zatvaranju svih graničnih prijelaza za ulazak u Republiku Srbiju. ${ }^{57} \mathrm{U}$ odluci se ne govori o povratku domaćih državljana u Srbiju, kao što je to Hrvatska učinila. Štoviše, predstavnici vlasti apelirali su na domaće državljane da se ne vraćaju u Srbiju i da ostanu u zemljama u kojima borave.

Osnovno pitanje koje se može postaviti je li ograničenje slobode kretanja na ovaj način proporcionalno cilju koji se želi postići u demokratskom društvu; je li stupanj ograničenja slobode kretanja proporcionalan stanju državne nužde i je li se svrha mogla postići i manje restriktivnim mjerama, koje neće najstarije građane držati u svojevrsnom "kućnom pritvoru" više od mjesec dana? Naravno da jest, a to pokazuje primjer Hrvatske, kao i mnogih drugih europskih zemalja, koje nisu na tako minuciozan način regulirale slobodu kretanja, a ipak su

51 Odluka o mjeri strogog ograničavanja zadržavanja na ulicama i drugim javnim mjestima, URbroj 511-01-300-20-10 od 21. ožujka 2020.

52 Odluka URbroj 810-06/20-01/7 od 20. ožujka 2020.

53 Odluka URbroj 511-01-300-20-14 od 23. ožujka 2020.

54 Ustavni sud Hrvatske odbacio je prijedloge za pokretanje postupka za ocjenu suglasnosti s Ustavom i zakonom, među ostalim, Odluke o mjeri strogog ograničavanja zadržavanja na ulicama i drugim javnim mjestima (broj U-II-1373/2020 i dr. od 14. rujna 2020).

55 Uredba o merama za vreme vanrednog stanja. Službeni glasnik RS, broj 31/2020, 36/2020 38/2020, 39/2020, 43/2020,47/2020, 49/2020, 53/2030, 56/2020, 57/2020, 58/2020.

56 Dana 18. ožujka uvedena je potpuna zabrana kretanja za osobe iznad 65 godina starosti; dok je za sve ostale vrijedila potpuna zabrana kretanja u razdoblju do 20 do 5 , tj. od 17 do 5 , počevši od 22. ožujka Osobama mlađim od 65 godina dopušteno je voditi kućne ljubimce (u određenim terminima). Osobama starijima od 65 godine dopušteno je kretanje tek 20. travnja u razdoblju od 18 do 1 utorkom, petkom i nedjeljom na udaljenosti od $600 \mathrm{~m}$ od mjesta prebivališta.

57 Odluka Vlade o zatvaranju graničnih prelaza, Službeni glasnik RS, broj 25 od 12. ožujka 2020., 27 od 13. ožujka $2020 ., 35$ od 18. ožujka 2020. 
postigle istovjetan cilj - sprječavanje širenja zaraznih bolesti. Osim toga, kako bi se razmotrili cjelokupnih učinci zabrane slobode kretanja, treba imati na umu da je ona utjecala i na uživanje drugih prava, poput prava djeteta i slobode vjeroispovijesti koja su apsolutno zaštićena prava. Pri ograničavanju slobode kretanja, posebne potrebe djece sa smetnjama u razvoju nisu uzete u obzir. Također, razvedeni roditelji imali su brojne nedoumice oko ostvarivanje prava na viđanja s djetetom tijekom izvanrednog stanja.

Ograničavanje, tj. potpuna zabrana kretanja tijekom uskršnjih blagdana, odrazila se na ostvarivanje slobode vjeroispovijesti. Tijekom Uskrsa bila je na snazi najduža zabrana kretanja, što je građanima onemogućilo da budu nazočni na vjerskim službama. Sloboda vjeroispovijesti, prema Ustavu Srbije, predstavlja apsolutno zaštićeno pravo, koje ne podliježe derogaciji u izvanrednom stanju. Međutim, srpski Ustav ostavlja mogućnost da se sloboda uživanja vjere ili uvjerenja može ograničiti zakonom, ako je to nužno u demokratskom društvu, među ostalim, i radi zaštite života i zdravlja ljudi. Ostaje otvoreno pitanje je li takav argument prihvatljiv i u kontekstu postojanja apsolutno zaštićenih prava u izvanrednom stanju. Ako pogledamo Europsku konvenciju, ona dopušta ograničenje uživanja vjerskih sloboda, među ostalim, radi zaštite javnog reda, zdravlja i morala. U kontekstu ostvarivanja slobode vjeroispovijesti spomenut ćemo Zaključak Vlade Srbije ${ }^{58}$ koji preporučuje da crkve i vjerske zajednice vjerske obrede vrše bez nazočnosti vjernika, a da se vjerski obredi pri pokopima obavljaju u nazočnosti ograničenoga broja ljudi. Sličnu je mjeru utvrdio i hrvatski Stožer civilne zaštite, ${ }^{59} \mathrm{~s}$ preporukama o sprječavanju zaraze tijekom obreda i obilježavanja vjerskih praznika.

Sloboda okupljanja sljedeće je pravo koje je bilo u posebnom režimu važenja tijekom "borbe" s koronavirusom. Jedna od prvih mjera koju je Stožer propisao odnosi se na mjeru socijalnog distanciranja, kojom se nalaže izbjegavanje bliskog osobnog kontakta u razmaku od najmanje dva metra u zatvorenom prostru i jednog metra na otvorenom prostoru. ${ }^{60}$ Protuepidemijska mjera koja je uvedena ovom Odlukom odnosi se na zabranu održavanja svih javnih događanja i okupljanja više od pet osoba na jednom mjestu.

U Srbiji je ograničenje sloboda okupljanja počelo prije uvođenja izvanrednog stanja, sličnom dinamikom kao i sloboda kretanja. Najprije je zabranjeno okupljanje više od 100 osoba (11. ožujka), zatim je taj broj smanjen na 50 (15. ožujka), a već 21. ožujka zabranjeno je okupljanje više od pet osoba. No, dopušteno je okupljanje do 50 osoba, ako okupljanje organizira nadležno državno tijelo, tijelo autonomne pokrajine ili tijelo jedinice lokalne samouprave radi nesmetanog rada i poduzimanja mjera usmjerenih na sprječavanje širenja bolesti COVID-19. Tijekom izvanrednog stanja izdvojit ćemo dva masovna okupljanja u kojima je predsjednik Republike odigrao središnju ulogu, a koja su se odnosila na podjelu kliničkih respiratora u Nišu i Novom Pazaru. ${ }^{61}$ Sasvim je izvjesno da se to moglo organizirati i bez nepotrebne medijske pompe u jeku epidemije.

Ključna razlika kad je riječ o odgovoru država koje uspoređujemo u vezi s poduzetim mjerama dolazi do izražaja kada su posrijedi jamstva u kaznenom postupku. Naime, u Srbiji je

58 Službeni glasnik RS, broj 43 od 27. ožujka 2020.

59 Odluka o načinu održavanja pogreba i posljednjih ispraćaja, URbroj 511-01-300-20-6 od 20. ožujka 2020.

60 Odluka o mjerama ograničavanja društvenih okupljanja, rada u trgovini, uslužnih djelatnosti i održavanja sportskih i kulturnih događaja, URbroj 511-01-300-20-1 od 19. ožujka 2020. 
veliku pozornost izazvalo donošenje Uredbe o načinu učešća optuženog na glavnom pretresu u krivičnom postupku koji se održava za vreme vanrednog stanja. ${ }^{62}$ Ovom Uredbom omogućava se sudjelovanje okrivljenika na glavnoj raspravi preko tehničkih sredstava za prijenos zvuka i slike. Odluku o tome donosi predsjednik vijeća, odnosno sudac pojedinac. Budući da se suđenje odvijalo preko Skypea, ova Uredba je popularno nazvana Uredba o suđenju preko Skypea. Ovdje ćemo dodati i stav Visokog saveta sudstva ${ }^{63}$ da se navedeni oblik suđenja primjenjuje samo na optužene koji se nalaze u pritvoru za tri kaznena djela ${ }^{64}$ i da je ne treba proširiti na ostale pritvorske predmete. Tome je prethodilo usvajanje zaključka kojim je utvrđeno da će se tijekom izvanrednog stanja održavati samo suđenja koja ne trpe odlaganja. ${ }^{65}$

U kontekstu navedene Uredbe, naglasit ćemo da nijednom odredbom Ustava Srbije, kao ni odredbom Zakonika o krivičnom postupku nije propisana mogućnost da se okrivljeni saslušava preko videolinka. Naprotiv, propisana je obvezna neposrednost. Optuženi za kazneno djelo, a dostupan sudu, ima pravo da mu se sudi u njegovoj nazočnosti i ne može biti kažnjen, ako mu je onemogućeno da bude saslušan i da se brani. ${ }^{66}$ Ustavno jamstvo prava na pravično suđenje obuhvaća procesno jamstvo da će se postupak u kojem se odlučuje o nečijim pravima i obvezama biti proveden na način da kroz neovisnost i nepristranost suda, javno raspravljanje, ravnopravno sudjelovanje u postupku, donošenja odluka u razumnom roku, primjenom i poštovanjem propisanih pravila postupka svakome bude omogućeno pravično suđenje. ${ }^{67}$ Pravo na pravično suđenje definira temeljne postupovne standarde kojima se moraju rukovoditi sudovi u svakom sudskom postupku, kako bi se sud mogao ocijeniti kao pravičan i u skladu s jamstvima predviđenim odredbama Ustava i Europske konvencije. ${ }^{68}$ Odluka suda o nečijem pravu ili obvezi mora biti donesena u postupku koji je proveden u skladu s važećim procesnim zakonom, primjenom relevantnog materijalnog prava i obrazložena na ustavno prihvatljiv način jer bi se u suprotnom moglo smatrati da je rezultat proizvoljnog i pravno neutemeljenog stanovišta postupajućeg suda. ${ }^{69}$ Do neke mjere može se prihvatiti da izvanredno stanje suspendira normalnu zaštitu prava u kaznenim postupcima, kako bi se pronašli i uhitili potencijalni teroristi prije nego što ponovno mogu napasti, ${ }^{70}$ što ovdje nije slučaj. Kako su rizici i opasnosti koje mogu dovesti do uvođenja izvanrednog stanja različiti, mjere odstupanja od ljudskih prava treba prilagoditi tome. Iste mjere se ne moraju primjenjivati u uvjetima prirodnih katastrofa i pandemija te u uvjetima kada postoji opasnost od terorističkih napada.

Spomenut ćemo Naredbu ministra zdravstva o organiziranju i provođenju mjere karantene, ${ }^{71}$ kojom je, među ostalim, uveden obvezan zdravstveni pregled za osobe koje su bila (ili se sumnja da su bile) u kontaktu s osobama oboljelima od zarazne bolesti. Sukladno Zakonu o

\footnotetext{
62 Službeni glasnik RS, broj 49/2020 od 1. travnja.

63 Zaključak br. 021-05-00040/2020-01 od 9. travnja 2020.

64 Nepostupanja prema zdravstvenim propisima za vrijeme epidemije, širenje zarazne bolesti i nedopuštene trgovine.

65 Zaključak br. 119-05-132/2020-01 od 18. ožujka 2020.

66 Članak 33. st. 4. ZKP-a.

67 Odluka Ustavnog suda Srbije Už 1147/2008.

68 Odluka Ustavnog suda IUz 1634/2010.

69 Odluka Ustavnog suda Už 4573/2012.

$70 \quad$ Ackerman, op. cit. u bilj. 5, str. 102. 
zaštiti stanovništva od zaraznih bolesti osobama kojima se određuje karantenska mjera uručuje se rješenje sanitarnog inspektora. Međutim, velik broj državljana Srbije koji se vratio iz inozemstva prije proglašavanja izvanrednog stanja i proglašenja epidemije, nije dobio rješenje sanitarnog inspektora. No, i oni su retroaktivno obuhvaćeni ovom naredbom. Sve osobe koje su prešle granicu Srbije, a koje nisu pronađene na adresi prijavljenog prebivališta u izolaciji, podlegle su kaznenoj odgovornosti za kazneno djelo nepostupanja prema propisima tijekom epidemije. ${ }^{72} \mathrm{Na}$ njih se primjenjivala i Uredba o Skype suđenju; oni su u vrlo kratkom roku bivali osuđeni na zatvorske kazne u maksimalnom trajanju (od tri godine). Time su derogirana elementarna prava: pravo na pravično suđenje (čl. 32. Ustava) i pravna sigurnost u kaznenom pravu (čl. 34. Ustava).

U kontekstu liječenja zaraženih osoba, Vlada je donijela odluke o otvaranju privremenih objekata za smještaj i liječenje osoba oboljelih od bolesti COVID-19 poput Beogradskog i Novosadskog sajma i dvorana Čair u Nišu. Ti su privremeni objekti utvrđeni kao dio vojnozdravstvenog sistema kojim u uvjetima izvanrednog stanja upravlja Ministarstvo odbrane i Vojska Srbije. Ovi objekti služili su za smještaj onih koji su imali lakšu kliničku sliku. Slike opremanja ovih objekata u javnosti izazivale su nespokoj i nemir kod građana.

Atmosfera represije u pandemijskim okolnostima dodatno je naglašeno Uredbom kojom se prekršajno kažnjava kršenje zabrane kretanja; kazna je novčana u rasponu od 50.000 do 150.000 dinara. ${ }^{73}$ Osim toga, Uredbom je određeno da se prekršaj može pokrenuti i dovršiti prekršajni postupak čak i u slučaju da je protiv počinitelja pokrenut ili je u tijeku kazneni postupak za kazneno djelo koje obuhvaća obilježje tog prekršaja, bez obzira na zabranu iz Zakona o prekršajima. Ovakvom normom prekršen je osnovni princip o zabrani dvostrukog kažnjavanja iz čl. 34. st. 4. Ustava (u vezi s čl. 33. st. 8.).

Zaključak Vlade o informiranju stanovništva o stanju i posljedicama zarazne bolesti, ${ }^{74}$ kojim se Krizni štab za suzbijanje zarazne bolesti na čelu s premijerkom zadužuje za informiranje javnosti o stanju i posljedicama zarazne bolesti, također je privukao veliku pozornost javnosti. Obavijest o poduzetim zdravstvenim mjerama i druge informacije u vezi s liječenjem bolesti COVID-19 koje nisu dobivene od ovlaštenih osoba ne mogu se smatrati točnim i provjerenim, uz mogućnost primjene propisa koji se odnose na odgovornost i pravne posljedice za širenje dezinformacija tijekom izvanrednog stanja. U kontekstu ovog akta spomenut ćemo da Ustav Srbije utvrđuje da svatko ima pravo da istinito, potpuno i pravodobno bude informiran o pitanjima od javnog značaja. Također, Ustav izričito zabranjuje cenzuru (čl. 51.). Ovakav Zaključak je vrlo brzo stavljen izvan snage, ali u bitnosti nije se mnogo toga promijenilo jer su sve važne informacije o broju oboljelih i preminulih priopćavane isključivo na konferencijama za medije Kriznog štaba. Nedavno je posebnu pozornost privukla analiza BIRN-a o neskladu između podataka u IS Covid 19 i onih koji su javno objavljeni. ${ }^{75}$

72 Članak 248. KZ-a.

73 Do 13. travnja 2020. prekršajno je kažnjeno 3300 građana prema različitim pravnim osnovima koji su vezani za zabranu kretanja u periodu epidemije novčanim kaznama u ukupnom iznosu od 136 milijuna dinara. Izvor: http://www.yucom.org.rs/wp-content/ uploads/2020/05/LJUDSKA-PRAVA-I-COVID-Pravo-na-pravi\%C4\%8Dno-su\%C4\%91enje-30.04.2020.pdf. Pristupljeno 16. svibnja 2020. 


\subsection{AKTI OGRANIČENJA LJUDSKIH PRAVA}

Uspoređujući odgovor Republike Hrvatske i Republike Srbije na bolest COVID-19 možemo primijetiti i razliku u tijelima nadležnim za donošenje mjera kojima se odstupa od ljudskih prava. Hrvatski Ustav utvrđuje da u slučaju neposredne ugroženosti neovisnosti, jedinstvenosti i opstojnosti države, ili kada su tijela državne vlasti onemogućena da redovito obavljaju svoje ustavne dužnosti, predsjednik Republike može, na prijedlog predsjednika Vlade i uz njegov supotpis, donositi uredbe sa zakonskom snagom. ${ }^{76}$ Predsjednik takve uredbe može donositi samo iznimno, ako se Sabor može sastati; ako predsjednik takve uredbe donese iako se Sabor mogao sastati, Sabor ih može konvalidirati većinom glasova, ali ako prethodno ustanovi da su ipak postojali opravdani razlozi za to. U protivnom, Sabor bi sankcionirao državni udar. ${ }^{77}$ Međutim, tijekom epidemije koronavirusa ove odredbe Ustava nisu se aktivirale, već su primijenjene odredbe Zakona o sustavu civilne zaštite i Zakona o zaštiti pučanstva od zaraznih bolesti. Glavnu ulogu u borbi protiv bolesti COVID-19 vodio je Stožer civilne zaštite. To je stručno, operativno i koordinativno tijelo za provođenje mjera i aktivnosti civilne zaštite u velikim nesrećama i katastrofama. ${ }^{78}$

U Srbiji, Narodna skupština usvaja mjere kojima se odstupa od ljudskih i manjinskih prava u izvanrednom stanju. Ako Skupština nije u mogućnosti da se sastane, ove mjere može propisati Vlada uz supotpis predsjednika Republike. Supotpis bi se mogao protumačiti kao instrument s pomoću kojeg se povećava legitimitet poduzetih mjera, s obzirom na to da dolazi od tijela koje izražava državno jedinstvo. ${ }^{79}$ Međutim, u praksi je to poprimilo drugačiji oblik. Predsjednik Republike nametnuo se kao centralni autoritet u donošenju propisa. Naime, predsjednik je u televizijskim prijenosima uživo najavljivao uvođenje mjera ili njihovu izmjenu, iako su one formalno usvojene na sjednicama Vlade, a pripremljene na sjednicama Kriznog štaba. Širenje normativne nadležnosti izvršne vlasti potvrdilo je primarnu ulogu predsjednika Republike. Paradoks je u tome što je Ustav Srbije (1990) predviđao snažne ovlasti predsjednika Republike u izvanrednim okolnostima. Važećim Ustavom Srbije željelo se izbjeći takav scenarij, uvođenjem aktivnije uloge Vlade. Tom prilikom potvrđena je praksa da položaj i ustavna uloga predsjednika Srbije ovise o ličnosti šefa države, snazi partijskog aparata koji je pod njegovom kontrolom i plebiscitarnoj politici, odnosno o njegovoj faktičnoj moći, a ne toliko o konkretnim ustavnim ovlastima. ${ }^{80}$

Uredbe za slučaj nužde donose se neposredno na temelju ustavnog ovlaštenja; one reguliraju ustavnu materiju i mogu se označiti kao uredbe ex constitutionem. ${ }^{81}$ Kada uredbodavac pristupa primarnom i načelnom normiranju, postoji njegova vezanost, prije svega, ustavom, a potom i zakonom, odnosno važećim zakonodavstvom. ${ }^{82}$ No, nije isključeno da se uredbe po

\footnotetext{
76 Članak 101. st. 2. Ustava Hrvatske.

77 Padjen, I., Uredbe iz nužde hrvatskog predsjednika: mjerodavnost francuskoga javnog prava, Politička misao, br. 1, 1996., str. 149.165.

78 Članak 22. Zakona o sustavu civilne zaštite.

79 Rajić, N., Instrumenti kontrole vlasti tokom vanrednog stanja na primeru Ustava Republike Srbije iz 2006. godine, Zbornik radova Pravnog fakulteta u Nišu, br. 57, 2011., str. 245.-255.

80 Stojanović, D., Ustavno pravo, SVEN, Niš, 2013., 389.

81 Jovičić, M., Ustav i ustavnost, Službeni glasnik, Beograd, 2006.

82 Jovičić, op. cit. u bilj. 74, str. 385.
} 
nuždi (Notverordungen) često donose contra legem. ${ }^{83}$ To se može opravdati činjenicom da je njihovo važenje privremeno; odnosno da prvi put kada se parlament može sastati, odlučuje hoće li se one transformirati u zakon ili prestati vrijediti.

Međutim, uz uredbe, mjere odstupanja od ljudskih prava utvrđena su još i naredbama i zaključcima. Tako je ministar unutrašnjih poslova donio naredbu kojom se ograničava i zabranjuje kretanje osoba na području Republike Srbije ${ }^{84}$ na osnovi ovlaštenja sadržanog u Uredbi o mjerama za vrijeme izvanrednog stanja. Međutim, ovakva naredba izlazi iz ustavnih okvira. Naime, Vlada i predsjednik Republike nisu ustavom ovlašteni za prijenos prava na donošenje uredbi na ministarstva unutar Vlade. To je vjerojatno i razlog što su kasnije ove zabrane integrirane u Uredbu o mjerama za vrijeme izvanrednog stanja.

\subsection{STATISTIČKA ANALIZA}

Odgovor promatranih država u vezi s bolešću COVID-19 dovest ćemo u vezu sa službenim statističkim podacima u vezi s brojem registriranih slučajeva i broja preminulih. Podaci koji se tiču Hrvatske preuzeti su mrežne stranice koronavirus.hr; podaci koji se odnose na Srbiju preuzeti su s mrežne stranice covid19.rs. Također, napomenut ćemo da broj stanovnika Hrvatske iznosi 4.105,673, ${ }^{85}$ dok taj broj u Srbiji iznosi 8.703,990. ${ }^{86}$ Prvi slučaj obolijevanja od koronavirusa u Hrvatskoj zabilježen je 25. veljače 2020. ${ }^{87}$ Ministar zdravstva proglasio je epidemiju bolesti COVID-19 uzrokovanu virusom SARS-CoV-2 dana 11. ožujka. ${ }^{88}$ U Srbiji, ove podatke promatramo počevši od 6. ožujka, kada je službeno registriran prvi oboljeli od bolesti COVID-19.

U tablici ispod prikazani su podaci koji se odnose na broj registriranih slučajeva i broj preminulih u periodu od registriranja prvog slučaja oboljenja do 25. rujna 2020.

Tablica 1: Broj registriranih slučajeva i broj preminulih (na dan 26. rujna 2020).

\begin{tabular}{|l|l|l|l|}
\hline Država & Broj potvrđenih slučajeva & Broj smrtnih slučajeva & Broj oporavljenih \\
\hline HRVATSKA & 16,007 & 269 & 14,405 \\
\hline SRBIJA & 33,312 & 746 & 31,536 \\
\hline
\end{tabular}

Na slikama ispod prikazan je broj novooboljelih na dnevnoj razini, kao i kumulativni broj oboljelih u jednoj i drugoj državi zaključno s 25. rujna 2020. Navedeni podaci preuzeti su s mrežne stranice worldmeters.info.

\footnotetext{
83 Marković, R., Izvršna vlast, Savremena administracija, Beograd, 1980.

84 Službeni glasnik RS, broj 34/2020, 39/2020, 40/2020 i 46/2020.

85 Izvor https://www.worldometers.info/world-population/croatia-population/. Pristupljeno 26. rujna 2020.

86 Izvor https://www.worldometers.info/world-population/serbia-population/. Pristupljeno 26. rujna 2020.

87 Izvor: https://koronavirus.hr. Pristupljeno 15. svibnja 2020 
Slika 1: Prikaz broja novooboljelih na dnevnoj razini

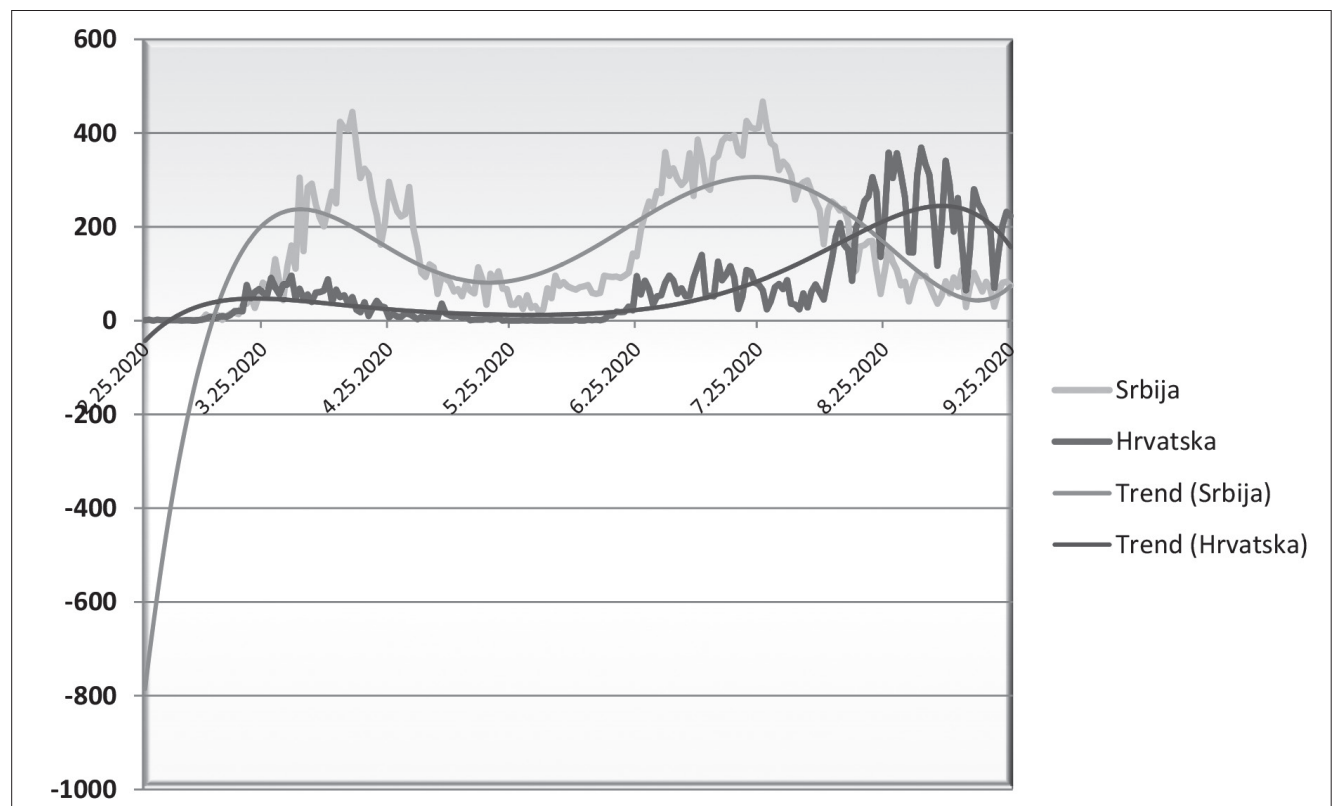

Slika 2: Prikaz ukupnog broja oboljelih

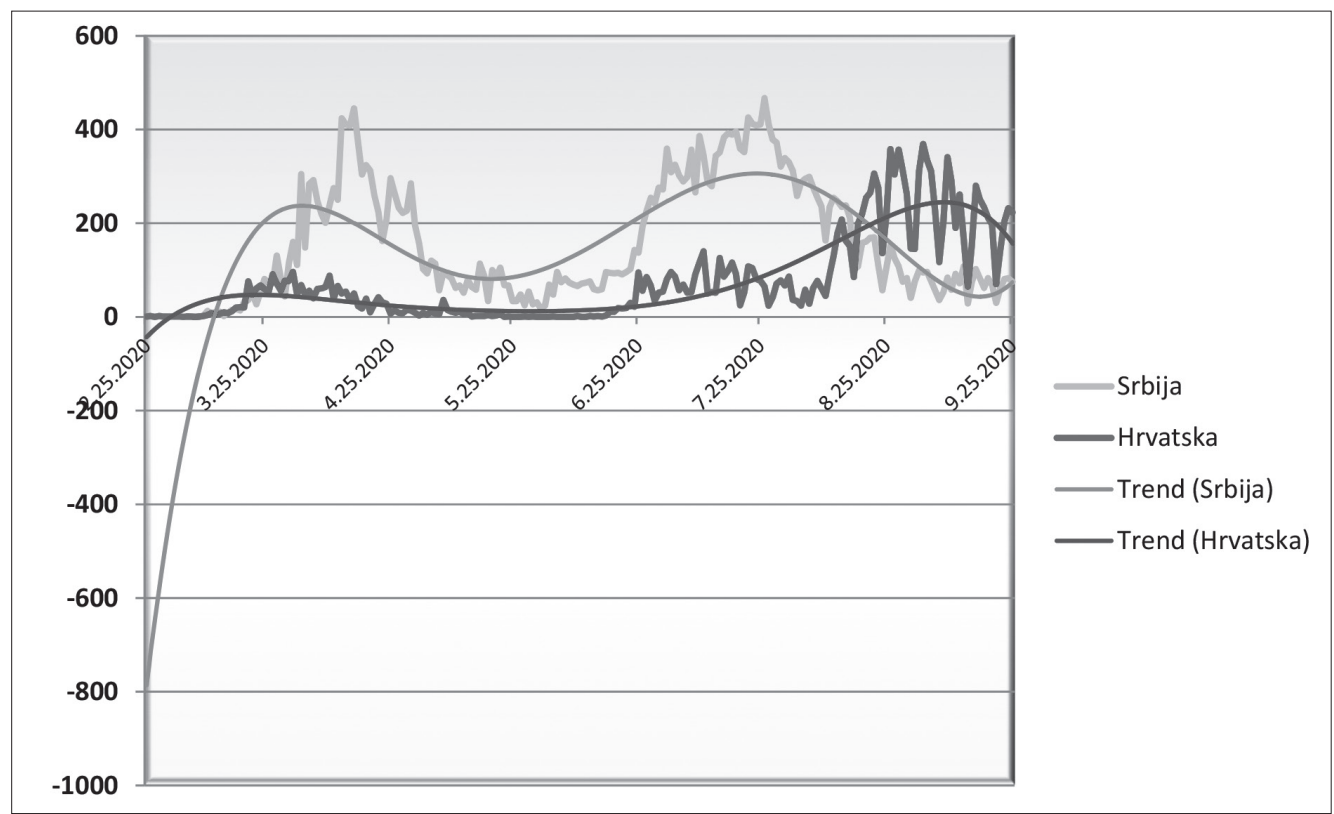

Na dijagramu novoboljelih na dnevnoj razini, krivuljama apsolutnih učestalosti (frekvencija) predstavljeni su brojevi prijavljenih slučajeva oboljelih od bolesti COVID-19 u razdoblju od 
šest mjeseci, od 25. veljače do 25. rujna 2020. godine. Budući da se zadane krivulje uzoračkih učestalosti mogu koristiti kao određena aproksimacija funkcija gustoće raspodjele, njihovim opserviranjem najprije zaključujemo da se analiza pojedinačnih vremenskih serija kao i njihova usporedba, mogu lakše provesti segmentirano, tj. u dva tromjesečna razdoblja. Promatrajući dijagrame prvog tromjesečja zaključuje se da:

1. Disperzija podataka u Srbiji znatno je veća. Ova činjenica ukazuje na mnogo veću nestabilnost srednje vrijednosti promatrane vremenske serije, što može biti inducirano neredovitim registriranjem podataka (u smislu da se rezultati testa dobiju nekad nakon jednog dana, a nekada se na rezultate čeka i do sedam dana) ili pak slabom kontrolom situacije na razini cijelog državnog područja (jer tako mogu izbiti iznenadna lokalna žarišta, koja doprinose odjednom velikom broju u ukupnom broju oboljelih).

2. Počevši od 24. ožujka prosječna vrijednost dnevnog broja registriranih slučajeva u Srbiji značajno raste karakterom geometrijske progresije tijekom sljedeća 3 do 4 tjedna, tako da se jasno ocrtava “zvonasti” karakter epidemiološke krivulje. Nasuprot tome, u Hrvatskoj će se sljedećih tjedan dana krivulja izravnati i broj novooboljelih postupno će se smanjivati. S obzirom na razdoblje inkubacije od 14 (odnosno 28 dana), ovaj trend opadanja jedino može biti posljedica vrlo brze i sustavne provedbe epidemioloških mjera u prvim danima epidemije.

3. Iako u slučaju Srbije imamo velike varijacije kako tijekom rasta, tako i tijekom pada, trend je primjetan u obje vremenske serije. Njegova prisutnost pokazuje se aproksimacijskim krivuljama polinomijalnog karaktera. Njime se lako može opravdati cijela priča iz točke 2. Međutim, interesantnija je činjenica da porast krivulje trenda u Srbiji u posljednjem tjednu promatranog razdoblja najavljuje novi porast broja novooboljelih. Suprotno tome, u Hrvatskoj oblik trenda najavljuje okončanje epidemije, što se praktički dogodilo krajem svibnja i u prvoj polovini lipnja.

$S$ druge strane, u drugom tromjesječju, statističkom analizom promatranih podataka, dolazimo do nešto drugačijih zaključaka. Naime:

1. U Srbiji je moguće, gotovo u potpunosti, preslikati stanje prvog tromjesečja. Trend najavljen porastom broja inficiranih, koji je bio jasno primjetan krajem prvog tromjsečja, u potpunosti je ostvaren. Jasno je uočljiv drugi val koji je, zbog odsutnosti bilo kakve korekcije državne mjere, samo još jači sa značajno većim ukupnim brojem novoinficiranih. Disperzija je i dalje jednako velika. A trend koji ne mijenja svoj izrazito polinomijalni karakter samo najavljuje još snažniji treći val koji se čini neizbježnim u idućem razdoblju. Novost analize podataka u Srbiji u ovom razdoblju, odnosno u razdoblju promatranom u svih šest mjeseci, ukazuje na postajanje evidentne sezonske komponente s razdobljem od jednog tromjesečja.

2. U Hrvatskoj, međutim, u drugom tromjesečju epidemije, odnosno početkom ljetnih mjeseci, dolazi do nešto nestabilnije situacije nego one s početka vremenske serije. Najznačajnije odstupanje u karakteru krivulje ogleda se u porastu disperzije koje je uvjetovano povremenim i kratkoročnim skokovima broja novooboljelih. S obzirom na to da je turizam u Hrvatskoj neusporedivo razvijeniji nego u Srbiji, a posebno zbog većeg prometa kapitala u ljetnim mjesecima, evidentno je bilo očekivati da zbog veće fluktuacije ljudi unutar regija u zemlji, a i određenog priljeva stranih turista dođe do većeg broja nekontroliranih socijalnih kontakata, koji su kao posljedicu dali ovakav karakter krivulje. Posljednjih tjedana promatranog razdoblja epidemije u Hrvatskoj evidentan je pad broj novoinficiranih, tako da se, u skladu s trendom 
opadanja koji je istodobno primijećen, može očekivati normalizaciju stanja koja bi se ogledala u smanjenju srednje vrijednosti vremenske serije kao i vrijednosti same disperzije krivulje.

\section{ZAKLJUČAK}

Analizirajući odgovor dviju država na bolest COVID-19 primjećujemo da obje pripadaju skupini država koje sadrže ustavne odredbe o izvanrednom stanju, čime se omogućava držanje države u okvirima vladavine prava u ovim iznimnim okolnostima. Oba ustava prepoznaju listu prava od kojih se smije odstupiti u ovim uvjetima. Međutim, u Hrvatskoj se nije posegnulo za uvođenjem izvanrednog stanja, derogirana su ona prava koja, u skladu s epidemiološkom situacijom usmjerena k zabrani kontakata i održavanju distance. Nije došlo do ekspanzije izvršne vlasti i Sabor je normalno funkcionirao.

U Srbiji, borba protiv bolesti COVID-19 odvijala se u uvjetima izvanrednog stanja i obilježena je izuzetno restriktivnim režimom važenja ljudskih prava, koji je dijelom bio u sukobu s ustavnim režimom. Okruženje u kojem su se ostvarivala ljudska prava, uz dominantnu vojnu retoriku i nedostatak demokratskih manira, dodatno su pojačavali negativnu atmosferu. Ograničenje ljudskih prava predstavljeno je kao jedna od najznačajnijih mjera u borbi protiv epidemije. Također, ustavni koncept apsolutno zaštićenih prava, koji je široko definiran, pokazao se neodrživim u praksi. Nažalost Ustavni sud Srbije, za razliku od Ustavnog suda Hrvatske (i dalje) nije smogao snage baviti se pitanjima ograničenja ljudskih prava.

$\mathrm{Na} \mathrm{kraju,} \mathrm{odgovor} \mathrm{analiziranih} \mathrm{država} \mathrm{doveden} \mathrm{je} \mathrm{u} \mathrm{vezu} \mathrm{s} \mathrm{relevantnim} \mathrm{statističkim} \mathrm{poka-}$ zateljima. Ovi podaci pokazuju da se dobar rezultat u borbi s bolešću COVID-19 može postići bez pretjeranih ograničenja ljudskih prava.

\section{LITERATURA}

1. Ackerman, B., The Emergency Constitution, The Yale Law Journal, Vol. 113, No. 5, 2003.-2004., str. 1029.-1091.

2. Alexy, R., On balancing and subsmption. A structural Comaprison, Ratio Juris, Vol. 16, Issues 4, 2003. str. 433.-449.

3. Avramović, D.; Mlađan, D., Vanredno stanje i vanredna situacija-komparativno terminološki i sadržinski aspekti, Teme, god. 2014., br. 1, str. 767.-781.

4. Beatty D., The Ultimate Rule of Law, New York, Oxford University Press, 2004.

5. Bulmer E., Emergeny Powers, International IDEA, Sweden, 2018.

6. Dutertre G., Izvodi iz sudske prarkse Evropski sud za ljudska prava, Sarajevo, 2002.

7. Fridrih, K., Konstitucionalna demokratija: Teorija i praksa u Evropi i Americi, Podgorica, 2005.

8. Emiliou, N., The Principle of Proportionality in European Law - A Comparative Study, Kluwer Law International, 1996.

9. Gujančić, D., Vanredno stanje - francusko iskustvo, Politička revija, vol. 23. br, 1, 2010., str. 165.-184. 
10. Jovičić, J., Položaj parlamenta za vreme vanrednog i ratnog stanja u ustavnom sistemu Republike Srbije, Nauka, bezbednost, policija, god. 20, br.1, 2015., str. 163.-172.

11. Jovičić, M., Ustav i ustavnost, Službeni glasnik, Beograd, 2006.

12. Lillich R., "The Paris Minimum Standards of Human Rights Norms in a State of Emegency", The American Journal of International Law, No. 4, 1985., str. 1072.-1081.

13. Mitrović, Lj.; Grbić Pavlović N.; Pavlović, G., Derogiranje ljudskih prava u vanrednom stanju - slučaj Bosne i Hercegovine, Pravni vjesnik, br. 3-4, 2016., str. 201.-209.

14. Marković, R., Izvršna vlast, Beograd, 1980.

15. Omejec, J., Ograničavanje sloboda i prava čovjeka i građanina u izvanrednim stanjima, Društveno istraživanje, Zagreb, god. 5, br. 2, 1996., str. 345.-376.

16. Padjen I., Uredbe iz nužde hrvatskog predsjednika: mjerodavnost francuskoga javnog prava, Politička misao, br. 1, 1996., str. 149.-165.

17. Pejić, I., The Constitutional rationalization of the separation of powers: the case of Serbia, Zbornik radova Pravnog fakulteta u Nišu, br. 84, 2019, str. 45.-62.

18. Rajić, N., Instrumenti kontrole vlasti tokom vanrednog stanja na primeru Ustava Republike Srbije iz 2006. godine, Zbornik radova Pravnog fakulteta u Nišu, br. 57, 2011., str. 245.-255.

19. Stojanović, D., Ustavno pravo, Niš, 2013.

20. Tucak, I., Pravna misao Hermanna U. Kantorowica i vrijeme nacionalsocijalizma, Zbornik Pravnog fakulteta u Zagrebu, br. 69, 5-6, 2019., 681.-714.

21. Šarin, D., Konvencija za zaštitu ljudskih prava i temeljnih sloboda kroz odnos Europskog suda za ljudska prava I Ustavnog suda Republike Hrvatske na primjeru zaštite ljudskog prava na pristup sudu, Pravni vjesnik, br. 3-4, 2014., str. 77.-100.

\section{POPIS PROPISA I SUDSKIH AKATA}

1. Guidance on Apps supporitng the fight against COVID 19 pandemic in relation to data protection.

2. Naredba o proglašenju epidemije zarazne bolesti COVID-19, Službeni glasnik RS, broj 37/2020.

3. Naredba ministra unutrašnjih poslova o ograničenju i zabrani kretanja lica na teritoriji Republike Srbije (Službeni glasnik RS, broj 34/2020).

4. Odluka o proglašenju epidemije bolesti COVID-19 uzrokovana virusom SARS-CoV-2, URbroj:534-02-01-2/6-20-01.

5. Odluka o proglašenju vanrednog stanja (Službeni glasnik RS, broj 29/2020).

6. Odluka o privremenoj zabrani prelaska preko graničnih prijelaza Republike Hrvatske, URbroj 51101-300-20-2 od 19. ožujka 2020.

7. Odluka o ukidanju vanrednog stanja (Službeni glasnik RS), broj 65 od 6. svibnja 2020.

8. Odluka o načinu održavanja pogreba i posljednjih ispraćaja, URbroj 511-01-300-20-6 od 20. ožujka 2020.

9. Odluka o mjerama ograničavanja društvenih okupljanja, rada u trgovini, uslužnih djelatnosti i održavanja sportskih i kulturnih događaja, Urbroj 511-01-300-20-1 od 19. ožujka 2020.

10. Rješenje Ustavnog suda Hrvatske U-I-1372/2020 i dr. od 14. rujna2020.

11. Odluka Ustavnog suda Srbije Už 1147/2008.

12. Odluka Ustavnog suda Srbije IUz 1634/2010. 
13. Odluka Ustavnog suda Srbije Už 4573/2012.

14. Rešenje Ustavnog suda Srbije IUo 42/2020 (Službeni glasnik RS, broj 77/2020).

15. Slučaj Aksoj protiv Turske.

16. Slučaj A. i drugi protiv UK

17. Slučaj Branningan i McBride protiv UK.

18. Zakon o odbrani (Službeni glasnik RS, broj 116/2007).

19. Zakon o smanjenu rizika od katastrofa i upravljanju vanrednim situacijama (Službeni glasnik RS, broj 87/2018).

20. Zaključak Vlade Srbije (Službeni glasnik RS, broj 43/2020).

21. Zaključak Visokog saveta sudstva br. 021-05-00040/2020-01 od 9. travnja 2020.

22. Zaključak Visokog saveta sudstva br. 119-05-132/2020-01 od 18. ožujka 2020.

23. Zaključak Vlade o informisanju stanovništva o stanju i posledicama zarazne bolesti (Službeni glasnik RS, broj 48/2020).

24. Zakon o sustavu civilne zaštite, (Narodne novine, broj 82/2015, 118/2018, 31/2020).

25. Zakonik o krivičnom postupku (Službeni glasnik RS, broj 72/2011, 101/2011, 121/2012 i 35/2019).

26. Ustav Republike Hrvatske (Narodne novine, broj 56/1990, 135/1997, 113/2000, 28/2001,76/2010, 5/2014).

27. Ustav Republike Srbije (Službeni glasnik RS, broj 98/2006).

28. Uredbe o načinu učešća optuženog na glavnom pretresu u krivičnom postupku koji se održava za vreme vanrednog stanja (Službeni glasnik RS, broj 49/2020).

\section{MREŽNI IZVORI}

1. Khakee, A., Obezbeđivanje demokratija? Komparativna analiza nadležnosti vanrednog stanja evropskih zemalja, Ženski centar de demokratsku kontrolu oružanih snaga, https://www.dcaf.ch/ sites/default/files/publications/documents/PP30-Anna.Khakee. Emergency.Powers-Serbian-final. pdf. Pristupljeno 12. travnja 2020

2. https://koronavirus.hr. Pristupljeno 15. svibnja 2020.

3. https.//worldmeters.info. Pristupljeno 15 svibnja 2020

4. https.//covid19.rs. Pristupljeno 15. svibnja 2020.

5. https://www.sharefoundation.info/sr/pandemija-jedne-lozinke/. Pristupljeno 25. travnja 2020.

6. https://www.poverenik.rs/sr-yu/covid-19-i-za\%C5\%A1titi-podataka-oli\%C4\%8 Dnosti. htm1?start=12. Pristupljeno 27. lipnja 2020.

7. https://www.mpravde.gov.rs/files/PREPORUKE\%20ZA\%20RAD\%20SUDOVA\%20I\%20 JAVNIH\%20TU\%C5\%BDILA\%C5\%A0TAVA\%20ZA\%20VREME\%20VANREDNOG\%20STANJA. Pristupljeno 23. ožujka 2020.

8. https://pravosudje.gov.hr/vijesti/preporuke-za-prevenciju-prenosenja-i-suzbijanje-epidemije-novim-koronavirusom -sars-cov-2-bolesti-covid-19/21707. Pristupljeno 9. travnja 2020.

9. https://vucic.rs/Vesti/Najnovije/a37251-U-Srbiji-nema-zarazenih-korona-virusom-vucic.rs.html. Pristupljeno 12. travnja 2020.

10. https://www.sabor.hr. Pristupljeno 18. svibnja 2020. 
11. http://www.yucom.org.rs/wp-content/uploads/2020/05/LJUDSKA-PRAVA-I-COVID-Pravo-na-pravi\%C4\%8Dno-su\%C4\%91enje-30. travnja 2020.pdf. Pristupljeno 16. svibnja 2020.

12. https://javno.rs/analiza/korona-broj-umrlih-i-zarazenih-visestruko-veci-od-zvanicno-saopstenog. Pristupljeno 28. lipnja 2020. 


\section{STATE RESPONSE TO COVID-19: THE CASE STUDIES OF CROATIA AND SERBIA}

\section{Summary}

Given the current pandemic coronavirus, the paper analyzes the state's response to the disease caused by the virus (COVID-19) from the standpoint of two neighbouring countries i.e. the Republic of Croatia and the Republic of Serbia. Special attention was paid to the states' response to the pandemic from human rights perspective. The research ws conducted into the patterns of their "struggle", especially as regards the human rights restrictions they had opted for within their constitutional framework. The starting point of the paper was that human rights often are the victims of the crises and that they are easily restricted for a longer periods. In this respect, the author deals with possible answers to the questions about the quality and content of human rights, and how the protection of human rights was ensured in these exceptional circumstances. This legal framework was linked to current statistics on the number of COVID-19 cases.

Having analyzed the response of the two states, it could be noted that both states have constitutional provisions governing the state of emergency, allowing them the rule of law in these exceptional circumstances. Both constitutions recognize a list of human rights that may be derogated in state of emergency. However, in Croatia, the state of emergency was not introduced, and the human rights were restricted in accordance with the given epidemiological situation.

In Serbia, the struggle against COVID-19 took place in state of emergency and was marked by an extremely restrictive regime of human rights, which was partly in conflict with the constitutional order. The constitutional concept of absolute protection of human rights, in their broadest sense, had proved unsustainable in practice.

Keywords: $\quad$ state of emergency, constitution, human rights, derogation, Croatia, Serbia

\section{(c) (1) (8)}

This work is licensed under a Creative Commons

Attribution-NonCommercial 4.0 International License.

Maja Nastić, PhD, Associate Professor, Faculty of Law, University of Niš, Trg kralja Aleksandra 11, 18000 Niš, Republika Srbija. E-mail address: maja@prafak.ni.ac.rs. ORCID: https://orcid.org/0000-0002-5545-6318. 